DOI: $10.20472 / T E .2016 .4 .3 .001$

\title{
PRACTICE ENTERPRISE AS A WAY OF ACQUIRING FOREIGN LANGUAGES - AN INTERNATIONAL SURVEY
}

\section{SIMONA PECKOVÁ}

\begin{abstract}
:
The article summarizes the main findings of the international survey in which we focussed on the usage of the practice enterprise as a way to improve one's knowledge of a foreign language and communication skills. The aim of the survey was to compare the experience in different countries concerning the language training, study materials etc. Interviewing several coordinators of the network of practice enterprises was our method of best practice sharing. Our survey has shown that in the Czech Republic, like in other countries, there are, however, some areas where more effort should be made. In order to reach the full potential of the practice enterprise as a means to improve pupils' level of foreign languages, we especially recommend creation of uniform materials and investments in the language instruction in general.
\end{abstract}

\section{Keywords:}

practice enterprise; language for specific purposes; learner autonomy; lifelong learning; competitiveness on the labour market; international comparison; study materials

JEL Classification: A21, J00, M10

\section{Authors:}

SIMONA PECKOVÁ, Charles University, Faculty of Education, French Language and Literature Department, Czech Republic, Email: peckova.simona@email.cz

\section{Citation:}

SIMONA PECKOVÁ (2016). Practice Enterprise as a Way of Acquiring Foreign Languages - an International Survey. International Journal of Teaching and Education, Vol. IV(3), pp. 1-6., 10.20472/TE.2016.4.3.001

The research was supported by the Charles University Grant Agency (project no. 332214). 


\section{Introduction}

Practice enterprise is a school subject taught in the Czech Republic since 1992, namely at upper-secondary commercial schools (Koudelková, 2012). The main reason why the subject was introduced to Czech schools was to help graduates find a job. In fact, only theoretical knowledge, gained at schools, is often insufficient since employers put a bigger emphasis on practical skills.

One enterprise is formed by 5 to 6 pupils, each of whom holds a certain position: director (he or she is responsible for smooth running of the company), assistant (inner and outer communication, conservation of mail), lawyer / human resources manager (concluding contracts, assessment of employees), marketer (creation of promotional materials), worker of the commercial department (purchasing and sale), accountant. At the beginning of the school year, the pupils choose the line of their business (usually on the basis of their hobbies) and they set up the enterprise, sticking to the effective rules of their country. During the school year, they create a website of their company and also some promotional materials. It is the correct administration of the given processes which is always emphasised. Students regularly present their companies at the trade fairs of practice enterprises (from regional to international level). The practice enterprises must respect the current laws and authentic commercial documents used within it (orders, invoices etc.). All the basic activities take place within the practice enterprises (purchase, sale, advertising, written and telephone communication, invoicing, accounting etc.). Unlike real companies, in practice enterprises, the are no real goods and money. (Rotport, Koudela, 2008, CEFIF, 2008).

Some of the practice enterprises do their business not only within their country, but also internationally. This kind of international commercial communication is an occasion for an authentic usage of a foreign language and so it could be classified as CLIL - content and language integrated learning (Marsh, Langé, 2000).

This concept of business simulation is spread in dozens of countries worldwide. At the international level, their activities are managed by a non-profit organization Europen International, which coordinates the central offices of the individual countries.

We do not have information about any research carried out in the world which would explore the possibilities of practice enterprise as a means to improve one's knowledge and communication skills in foreign languages. However, there have been projects aiming to improve the work of practice enterprises. In the Czech Republic, these were projects called Graces 1999 and Graces 2000, organised by the University of Economics in Prague. Moreover, EU experts acknowledge the importance of this concept of instruction. As a result, there is an online learning tool being created (thanks to the EU education funds) called PELLIC (Practice Entreprise for Language Learning and Intercultural Communication) (Koudelková, 2012). This 
platform would enable pupils to improve their foreign language knowledge and communication skills which they need for their work within the practice enterprise.

In our previous research (Pecková, 2016), we were mapping the situation of the practice enterprises in the Czech Republic and we identified the problems that pupils, teachers and coordinators encounter during their work. Now we focussed on a comparison with the other countries where the practice enterprise is taught.

\section{Research}

To collect our data, we used a qualitative method of research. Concerning the tools of research, we used interview (due to organisational reasons in a written form). We interviewed several coordinators of the practice enterprises in different countries. The coordinators of the following countries agreed to take part in our research: Canada, Bulgaria, the Slovak Republic, Lithuania, Finland and Brazil. The coordinators were asked the following questions (in the English language):

1) What is approximately the percentage of practice enterprises in your country that do business internationally?

2) Do the students have any special language training for that?

3) Do they have any study materials created specifically for that purpose?

4) In your opinion, what is the attitude of students towards the practice enterprise? (do they consider it important, difficult, entertaining ...? - compared to the other subjects)

5) What are the problems the teachers of PE encounter during their work?

6) What are the strong and weak points of PE as a way to learn foreign languages?

Concerning the first question, the proportion of practice enterprises which do business internationally roughly corresponds to the quality and the extent of the instruction of foreign languages in these countries in general. Among the countries that took part in the survey, this proportion is the smallest in Brazil (approximately $10 \%)$. Then it is Bulgaria, Slovakia and Lithuania that follow - here, the proportion is $20 \%$. In Finland (which is well-known for its high level of the English language) the proportion is $50 \%$. And finally $75 \%$ in bilingual Canada. The central office in the Czech Republic (Centrála fiktivních firem CEFIF) does not collect this kind of data. We estimate it could be comparable to Slovakia, i.e approx. $20 \%$.

Neither in the Czech Republic nor in the other countries are the pupils systematically prepared for business communication with their business partners from foreign countries (they have to make do with the knowledge and skills acquired in lessons of a general foreign language). An interesting and probably useful method seems to be the "foreign languages day" organised by the Lithuanian centre of practice enterprises. Here the pupils go through a certain basic training in business English. In 
some of the Finnish schools, practice enterprise is incorporated in the courses of English. In bilingual Canada, pupils are required to communicate within the practice enterprise in both these languages (English, French) and also the promotional materials are always made in two language versions.

In countries taking part in our survey (like in the Czech Republic), there is no unified study material for this purpose. The schools are autonomous to decide about the kind of language preparation. In case there are some study materials, usually, they have been created by the teachers, sometimes in cooperation with the national central office of the practice enterprises. In Slovakia, for example, there was a study material in the German language created within the Phare programme. Concerning the Czech Republic, in 2000, a dictionary of business terminology was created in three language versions (English, German, French). A set of activities helping to develop business communication skills especially useful within the practice enterprise was one of the outputs of our preceding research (Pecková, 2015), where we focussed exclusively on the situation in the Czech Republic. Given the orientation of the author, this study material was made in two language versions - English and French.

All the interviewed coordinators agreed on the fact that practice enterprise is one of the school subjects pupils usually enjoy. Often they spend some of their free time working for their company, as the amount of lessons at school (usually 4 lessons per week) is not sufficient. The coordinators unanimously agreed that a positive attitude of students is a key factor of success.

Concerning the problems the teachers of practice enterprise encounter during their work, they mention lack of time and high requirements put on teachers regarding their knowledge and practical experience. Due to the fact that the subject is not compulsory, some pupils consider it less important and pay less attention to it than they should.

According to the coordinators, one of the strong points of the practice enterprise as a means of acquiring a foreign language is the fact that it is an occasion to use the language in an authentic way. The communication in a foreign language within the practice enterprise seems to be very motivating, because the students can clearly see the objective of their effort (they do not study to get good grades but to sell their product) (Pecková, 2016). There are many occasions to speak as there are thousands of business partners within the worldwide network of practice enterprises.

On the other hand, the language level of practice enterprise teachers is often insufficient. Among the countries that took part in our survey, it is only in Canada where a teacher of a foreign language participates in the teaching process on a parttime basis. Otherwise it depends on the headmaster of the school if he or she supports financially the cooperation with a foreign language teacher (in the Czech Republic, for example, pupils come to language teachers to consult the problems in teachers' free time). Another weak point is that not everyone can learn everything, as 
each pupil only gets one position in the company and so he or she focuses only on a particular area of activities within the business.

\section{Conclusion}

Practice enterprise is a kind of autonomous learning (Cuq, 2005), it develops the pupils' inner motivation (Rogers, 2002) and so it goes hand in hand with the principles of lifelong learning. It often fills the pupils with enthusiasm, it is usually one of their favourite school subjects. Also the weaker pupils are here enabled to succeed and to excel. The practice enterprise often contributes to creation of good relationships between the pupils.

Doing business internationally within the practice enterprise may help pupils improve their knowledge of grammar, vocabulary and pronunciation. It may also improve all the kinds of communication skills (Hendrich, 1988). Speaking and listening is practised during the school year via phone calls to the other companies and also at the international trade fair of practice enterprises, taking place each year. Writing and reading is then practised during the email communication and also when pupils have to create a foreign-language version of their promotional materials. Communication in a foreign language within the practice enterprise helps pupils experience the feeling of success. We think that this is an extremely important springboard and that this is the reason why practice enterprise could help form in pupils a positive attitude towards foreign languages (Pavelková, 2002, Pecková 2015).

At primary and secondary schools pupils may learn general language which is often not sufficient for working life. Languages for specific purposes (Carras et coll., 2007, Hendrich, 1988, Hutchinson, 1987) are taught only marginally and not at a level which would correspond to the requirements of real business communication. Even within the practice enterprise, the business language is now taught only sporadically and not in a systematic way.

Practice enterprise makes it possible to acquire many skills of various kinds. If the enterprise does business internationally, this subject may be a way to improve the level of business language. In the Czech Republic, like in the other countries, this potential of practice business is not fully reached so far. The example of Canada and Finland may show why. It seems that the extent of using the practice enterprise as a means how to improve the level of a foreign language is directly proportional to the quality of language instruction in general. Thus we consider that investments in instruction of foreign languages are necessary.

The survey made in the Czech Republic and in the other countries has shown that practice enterprise is a method of teaching that bears potential to (besides other things) improve pupils' level of foreign languages. To make the most of it, it is necessary to pay more attention to this concept of teaching and learning. The language preparation within practice enterprise should be approached in a more unified and systematic way. Most teachers say (Pecková, 2015) that there are so 
many things to teach during the course of the practice enterprise that there is no time for language preparation. So not much can be changed without an important increase of lessons taught per week. Also, introduction of unified study materials is vital. Last but not least, a closer and a more systematic (and paid) cooperation with teachers of foreign languages could be a way to overcome the problem of insufficient language competencies of the teachers of practice enterprise.

\section{Reference}

CARRAS, C., TOLAS, J., KOHLER, P., SZILAGYI, E.: Le Français sur Objectifs Spécifiques et la classe de langue, CLE international, 2007, 207 s.

CEFIF, Fiktivní firmy v České republice 1992 - 2008, Praha: NÚOV 2008

CUQ, J.-P., GRUCA, I.: Cours de didactique du français langue étrangère et seconde, PUG, 2005, 504 $\mathrm{s}$.

HENDRICH, J.: Didaktika cizích jazyků, Praha: SPN, 1988, $498 \mathrm{~s}$.

HRABAL, V., PAVELKOVÁ, I.: Jaký jsem učitel, Praha: Portál, 2010, 240 s.

HUTCHINSON, T. WATERS, A.: English for specific purposes: a learning-centred approach, CUP, 1987, $183 \mathrm{~s}$.

KOUDELKOVÁ, S. Zpráva z fóra k projektu PELLIC. Acta oeconomica Pragensia: Vědecký sborník Vysoké školy ekonomické v Praze, 2012, roč. 2012, č. 3, s. 98 - 100. ISSN 0572-3043.

KOUDELKOVÁ, S. 20. výročí konceptu fiktivních firem vČeské republice. Acta oeconomica Pragensia: Vědecký sborník Vysoké školy ekonomické v Praze, 2012, č. 6, s. 98 - 99. ISSN 0572-3043.

MARSH, D., LANGÉ, G.: Using Languages to Learn and Learning to Use languages, University of Jyväskylä, 2000, $150 \mathrm{~s}$.

PAVELKOVÁ, I.: Motivace žáků k učení, Praha: UK, 2002, 248 s.

PECKOVÁ, S. : Fiktivní firma jako prostředek osvojování cizích jazyků, disertační práce, Praha, PedFUK, 2015, 186 s.

PECKOVÁ, S. Fiktivní firma jako prostředek osvojování cizích jazyků. BIT: Vědecký sborník Vysoké školy práva a podnikání, 2016, roč. 2012, č. 2, ISSN 1805-3777.

ROGERS, A.: Teaching Adults, Open University Press, 2002, 294 s.

ROTPORT, M., KOUDELA, J.: Didaktika předmětu práce ve fiktivní firmě, CD ROM, Praha: VŠE, 2008

Zpráva z Projektu GRACES 1999, Sbližování koncepce fiktivních firem v České republice a v zemích EU, řešitelé [15] ROTPORT, M., BOČÁNKOVÁ, M., DVOŘÁČEK, J., ŽIROVNICKÁ, J.

Zpráva z Projektu GRACES 2000, Zvyšování kvality práce fiktivních firem v České republice a jejich sbližování s úrovní v zemích EU (s dưrazem na rozvoj jazykových schopností žáků 